\title{
Quantifying the Accessibility of Sustainable Seafood in Southeast
}

\section{Queensland, Australia}

Tia Vella ${ }^{1}$, Carissa Klein ${ }^{1 *}$

${ }^{1}$ School of Earth and Environmental Sciences, The University of Queensland

*Corresponding author: c.klein@uq.edu.au

\section{Ethics Approval}

A University of Queensland ethics exemption was granted for this study, 17/02/2021 29/10/2021. Project number: 2021/HE000078.

\begin{abstract}
Seafood is a nutritious source of protein for billions of people around the world and is generally more sustainable than other animal-based protein sources. As the human population grows, seafood will continue to play an important role in feeding the world. The sustainability of seafood products differs, depending on the species consumed, origin, and production/fishing method. Having access to sustainable seafood products is essential to ensure future generations can continue to consume seafood. We aimed to determine the accessibility of sustainable seafood products to consumers in southeast Queensland, Australia. We surveyed 52,447 fresh, cooked, and processed (packaged) seafood products across southeast Queensland from 2110 establishments (restaurants, supermarket, takeaway shops). We investigated the species, origin and catch method of seafood products and used this information to determine their sustainability according to the Good Fish Guide developed by the Australian Marine Conservation Society. We found enough information to determine the level of sustainability for $36 \%(n=18,709)$ of surveyed products: $4.9 \%$ were sustainable, $4.1 \%$ were classified as 'Eat Less', and $27 \%$ were classified as 'Say No'. The 64\% $(n=33,737)$ of products that we could not assess was due to the lack of information at point of sale $(16 \%)$ or the product was not included in the Good Fish Guide (48\%). The top three most accessible sustainable products were Australian farmed barramundi, oysters and prawns. The three most common products to 'Say No' were Australian farmed Atlantic salmon, imported prawns and basa. We found that $44 \%(n=12,040)$ of products listed in the Good Fish Guide were lacking origin information. Improving the labelling of species, origin, and catch method
\end{abstract}


of seafood products at the point of sale, especially detailed information about a product's origin, is essential to improving the accessibility of sustainable seafood.

Key Words: Labelling, Seafood Guides, Consumers

\section{Introduction}

Sustainability is a significant issue facing the global society. It is defined as the ability of present generations to meet their requirements without compromising future generations' ability to meet their own requirements [1]. Sustainable development is driving many initiatives around the world which are underpinned by the United Nations Sustainable Development Goals [2].

One of the greatest sustainability challenges is feeding a further two billion people without incurring an overwhelming environmental impact. Seafood will continue to play a key role in solving this challenge as it is generally more environmentally efficient than other sources of animal-based proteins $[3,4]$. Globally, fish consumption has increased, at a rate of $3.1 \%$ each year from 1961 to 2017 [5]. This reliance on fishing has caused fish populations to decline across the globe [6], which have associated negative implications for marine ecosystems and people [7-9]. Improving the sustainability of seafood benefits the ocean, and associated ecosystems, as well as the people it supports.

There are multiple ways of defining sustainable seafood, with a typical focus on environmental sustainability as the key component of definitions [10]. In general, the sustainability of seafood is determined by the method of production (i.e. wild caught or farmed). For example, fisheries are considered to be sustainable when the stocks of target species are well managed, destructive fishing practices and bycatch levels are minimised, and the system is deemed as viable into the future [11]. Similarly, aquaculture systems are considered to be sustainable when there is efficient and economically viable production, and positive interactions with local communities and the surrounding environment [12]. However, due to the variation in sustainability definitions, products that are considered to be sustainable by one organisation may not be considered sustainable by another [11].

In 2017 it was estimated that only $65.8 \%$ of global fisheries have fish stocks within biologically sustainable levels, with $34.2 \%$ fished at biologically unsustainable levels [5]. However, the demand from consumers to have access to sustainable seafood products is growing as sustainability awareness and education grows, with consumers starting to push for 
more locally acquired and sustainably sourced seafood products, often willing to pay more for these sustainable products [13-15]. This has spurred an increase in prevalence of ecolabels and seafood certification schemes such as the Marine Stewardship Council for wild capture fisheries, and the Aquaculture Stewardship Council for farmed seafood products. These aim to certify sustainably managed fisheries and farms, as well as providing an easy way for consumers to recognise sustainably produced seafood products $[16,17]$.

In Australia, seafood is an important source of protein, with Australians consuming an average of $13.7 \mathrm{~kg}$ of seafood per person in 2017-18 [18]. Australia has numerous policies managing fishery operations, such as the Fisheries Management Act 1991, which support sustainability and conservation [19]. The seafood Australia produces is not necessarily consumed in Australia given that globally, seafood is one of the most traded commodities. Australia exports approximately $19 \%$ of the seafood it produces and imports around $70 \%$ of its seafood from overseas [18]. Thus, the seafood that is consumed in Australia may not be sustainable, despite Australia's allegedly rigorous marine conservation and sustainability policies.

Australian seafood labelling laws do not mandate that all the information required to assess sustainability be provided to the consumer, especially in the case of cooked products. This makes it challenging to assess sustainability using readily available seafood sustainability guides such as the Australian Marine Conservation Society's Good Fish Guide [20]. This study aims to determine how accessible sustainable seafood is to consumers in southeast Queensland, Australia. We hypothesise that sustainable seafood is difficult to obtain for the average consumer.

\section{Methods}

Study region and data collection

We conducted this study in Southeast Queensland, Australia, a region with a population of 3,366,880 [21] across 12 local government areas (LGA) (Figure 1). We designed a survey to assess the sustainability of fresh, frozen, cooked and processed seafood products based on the Australian Marine Conservation Society (AMCS) guide, Good Fish [20]. The guide was chosen as it is freely available to the public via an online website and phone application and is specifically designed for use by Australian consumers to assess the sustainability of 
seafood products they are likely to encounter in Australia. The guide categorises the sustainability of common seafood products found in Australia into three categories based on information such as species, origin and catch method [20]: "Better Choice" ( most sustainable categorisation), Eat Less (some sustainability concerns), and "Say No" (least sustainable categorisation). The survey (Appendix 1) included questions targeting the information required for consumers to determine the sustainability of a seafood species, specifically focusing on species, origin and catch method information for any fresh, cooked, frozen, or canned seafood product.

We conducted surveys across the 12 LGAs at any establishment that sells seafood to the general population, including restaurants, supermarkets, and takeaway venues. We determined a sample size for each LGA (95\% confidence, $5 \%$ margin of error) of 62-348 establishments, depending on population size and how many potential establishments in each LGA sell seafood products (Table 1). To determine the initial sample size, we used publicly available food licence data which was provided by four LGAs [22-25], with the potential number of seafood establishments excluding schools, hospitals, nursing homes and childcare centres, as well as establishments which definitely do not sell seafood products such as ice cream parlours and some fast food chains [26]. We extrapolated the number of potential establishments for the 8 LGAs that did not provide this data based on an area with a similar population size. When surveying, we further refined the number by counting the number of establishments that sold seafood products versus did not (not counting establishments already removed), which we used to estimate the proportion of seafood establishments in each LGA that was surveyed in-person. We multiplied the proportion by the potential number of seafood establishments for each LGA, to determine a more accurate sample size (Table 1).

Table 1: Samnle size and survevs comnleted for establishments and seafood products in

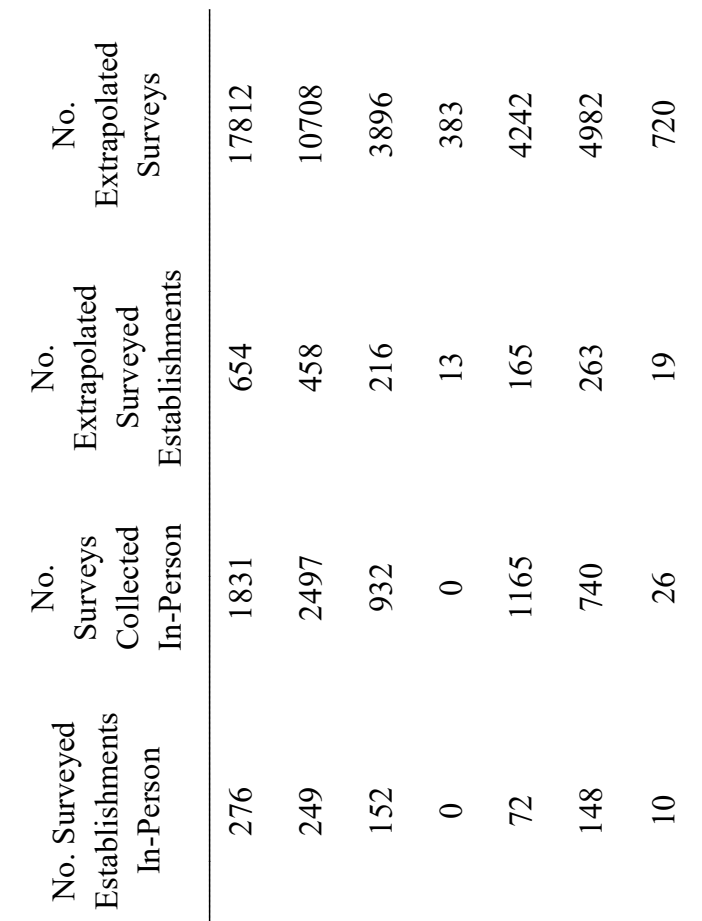


We aimed to engage volunteer citizen scientists to help conduct surveys, as they have been beneficial to numerous studies $[27,28]$. To do this, we created the survey using google forms so that it was simple and easy to access by volunteers. We also created a website (https://sustainableseafoodsurvey.wordpress.com/) which provided detailed instructions of how to fill in the survey to ensure consistency among entries. To recruit citizen scientists, we gave presentations to over 80 students and staff at The University of Queensland, sent emails to environmental/marine science university groups (e.g. Centre for Biodiversity and Conservation Science), used social media, and hung posters around The University of Queensland. Additionally, we ran a field trip around the Brisbane City and Redland City LGAs with 8 participants. Despite these efforts, limited surveys were completed by citizens. As the survey entrant was not identifiable, we cannot determine the exact number completed by citizens, but estimate that we (Vella and Klein) conducted $96 \%$ of the surveys. We conducted all surveys in-person, using a door-to-door method, to every open establishment at the time in an area. At each establishment, survey questions were completed through observation of the information first, followed by one to two questions to a server if information was unable to be observed on menus or product labels.

Analysis

The data were extrapolated for establishments based in multiple locations that confirmed they had the same products and supplier for each chain (e.g. McDonalds). For major supermarkets which had limited variation across their stores (e.g. Coles and Woolworths), a typical store for each chain was created based on the surveyed stores and then extrapolated for the number of stores across southeast Queensland. The most variation for the supermarkets was found in the fresh/raw seafood section of the stores, with all other packaged seafood products having a very similar range across all surveyed stores. 
We assessed each survey entry using the AMCS Good Fish Guide, to determine the sustainability category of the seafood product. The guide uses three main categories to sort seafood species: Better Choice, Eat Less and Say No [20]. The seafood products with species which were not listed in the guide were given the category "NA". Some seafood products did not have enough information to categorise. However, in some cases we were able to determine the missing information so that we could assess their sustainability. For example, farmed Australian products for a particular species have the same sustainability categorisation for all locations around Australia; thus if we knew that a barramundi product was farmed in Australia, we could assume it was a Better Choice, without specific origin information being provided. When the given species information was searched in the Good Fish Guide and there were multiple different species options to choose from, the species information was deemed to be not specific enough and categorised in our analysis as unknown. This applied to broad categories of species such as prawn and cod, as well as narrower groups of species such as tuna, which have multiple species listed. For example, 14 prawn products are included in the guide covering all three sustainability categorisations, but they are often sold without all the information to determine the exact product. Similarly, origin information was considered unknown if it was not given or if it was not specific enough to use the guide to determine the sustainability categorisation. For example, the Good Fish Guide categorises barramundi caught in Queensland fisheries as Say No, however, barramundi caught in the Northern Territory or Western Australian fisheries are categorised as Eat Less [20]. Catch method information was based on presence or absence of the information. In addition, we assessed the entries for wild caught Australian species using the stock status sustainability categories of the Fisheries Research and Development Corporation (FRDC). The FRDC works in partnership (including receiving funding) with the Australian government to ensure sustainability of fisheries and marine ecosystems [29].

Using the survey, we also collected data on other aspects of seafood products, such as the sustainability certification and price, which were not analysed in this study (Appendix 2). We were granted an ethics approval for this project and therefore, establishment names which were collected as part of the initial dataset, to avoid replication, were not able to be analysed for their sustainability. We analysed the data using R and R Studio [30] and graphs were made using ggplot2 [31].

\section{Results}


We surveyed 1049 different establishments covering 8498 products across southeast Queensland (Table 1). The extrapolated data across chain restaurants and supermarkets covers 2111 different establishments and 52,447 products (Table 1). We found that 18,709 products had enough information to assess sustainability using the AMCS Good Fish Guide. A limited amount of products were categorised as a Better Choice by the AMCS Good Fish Guide $(4.9 \%, \mathrm{n}=2587)$, with the majority of products being categorised as NA $(48 \%, \mathrm{n}=$ $25,315)$ followed by Say No $(27 \%, n=13,991)$, not enough information $(16 \%, n=8421)$ and Eat Less $(4.1 \%, \mathrm{n}=2129)$. There were 187 species which were not listed in the guide, (or had missing conditions such as origin which was not listed for that particular product). We surveyed the greatest number of seafood products in supermarkets $(92 \%, n=48,508)$ and were where we found the highest number of Better Choice options (Figure 2a). Frozen packaged seafood items were the most common product type for seafood products $(33 \%, n=$ 17,541), with the easiest form to find sustainable, Better Choice, seafood products was in their fresh/raw form $(3.8 \%, n=1983)$ (Figure $2 b)$.

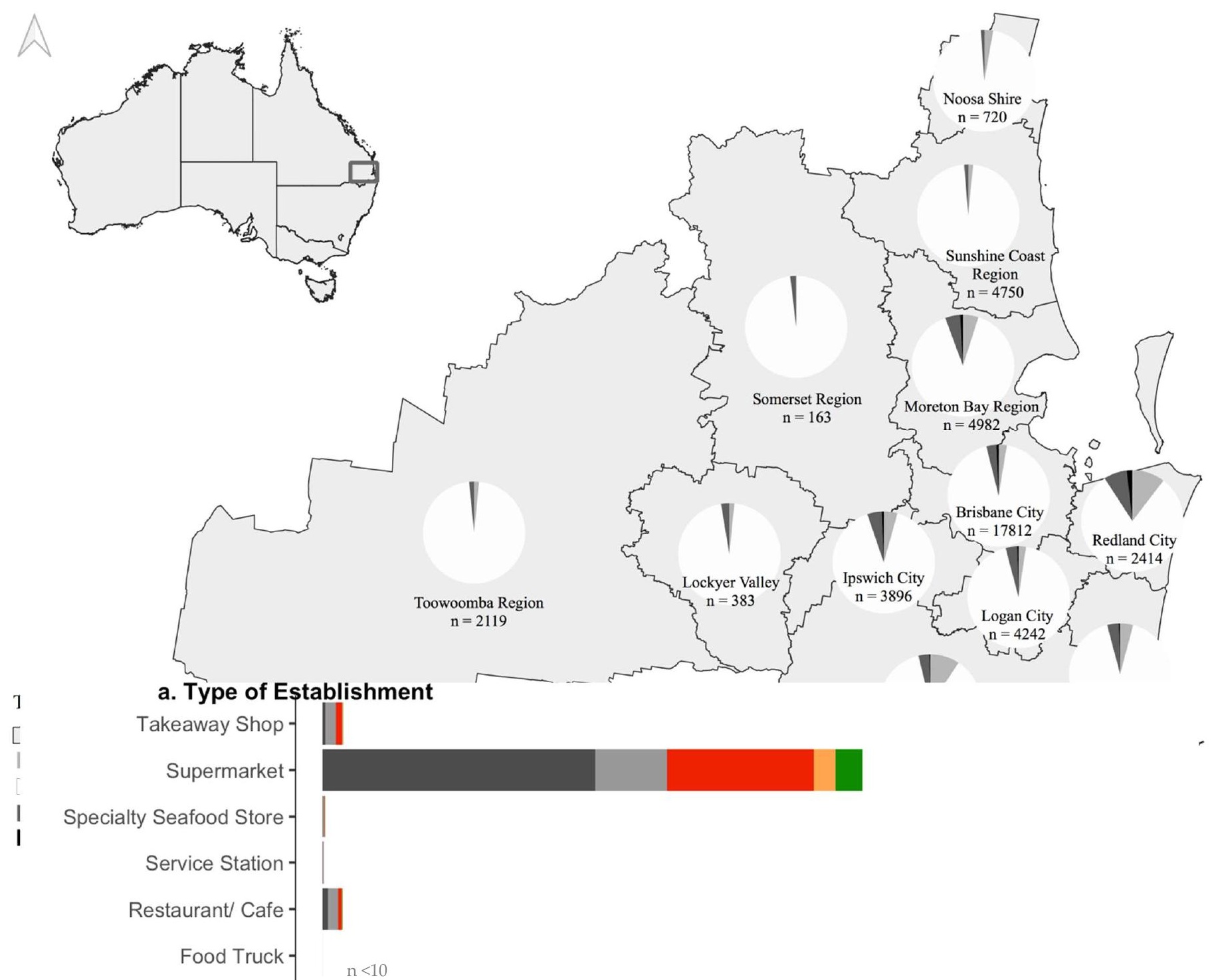


Figure 2: The sustainability of seafood products surveyed $(n=52,447)$ were assessed using Australia's Good Fish Guide [20] across a range of establishments (a) and for a variety of products (b). The guide categorises seafood products into three categories: 'Better Choice', 'Eat Less' and 'Say No'. Some of the seafood products surveyed could not be categorised due to a lack of information or were not in the guide (NA).

We found that across the surveyed products listed in the Good Fish Guide, only $40 \%$ ( $\mathrm{n}=$ 10,843 ) had all three types of information required to determine their sustainability category known. Adequate origin information was the most commonly lacking element $(44 \%, n=$ 12,040) (Figure 3a). We analysed the 8421 products which did not have enough information to be categorised for their Good Fish Guide sustainability category, to determine what types of information was lacking and preventing them from being categorised. Of the products that could not be categorised, the largest information gap in these products was origin information, with $93 \%(n=7832)$ of seafood products completely missing origin information or not having detailed enough information to allow the sustainability category of the product to be determined (Figure $3 \mathrm{~b}$ and $\mathrm{c}$ ). Cooked products were most commonly lacking information $(n=2120)$, whereas canned $(n=761)$ products usually provided enough information to categorise them (Figure 3b). Restaurants/cafes and takeaway shops were more likely to lack the required information to assess sustainability than supermarkets, and had a much higher proportion of products unable to be categorised $(53 \%, \mathrm{n}=1908)$ compared to supermarkets $(13 \%, n=6430)$ (Figure $3 c)$.
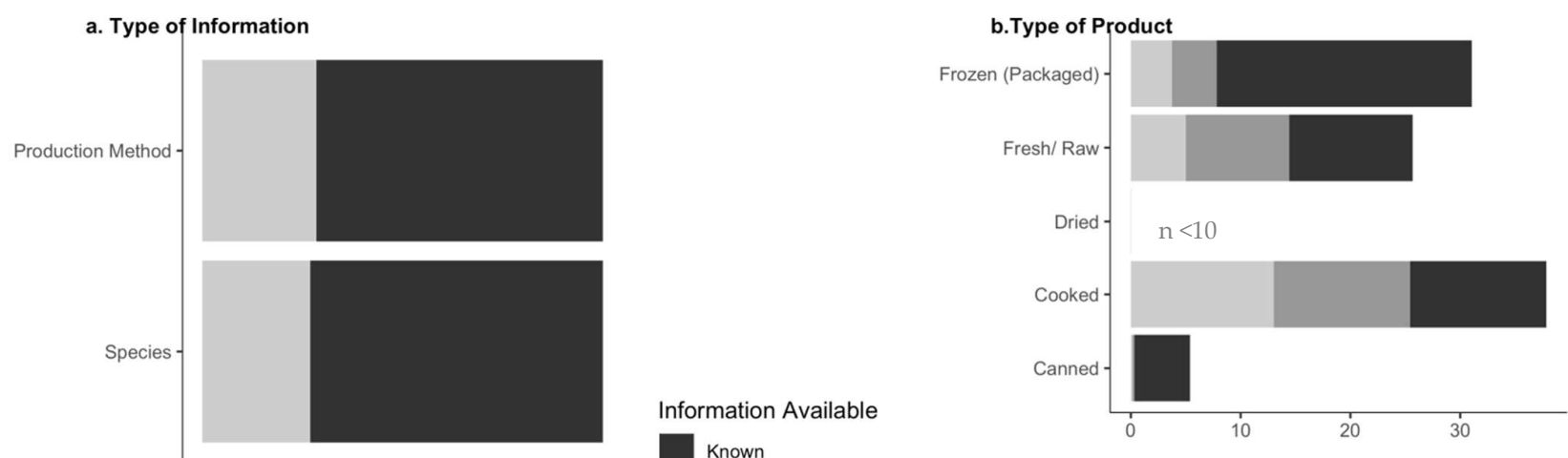
Figure 3: Surveyed seafood products listed in the Good Fish Guide $(n=27130)$ [20] were assessed to see what type of information was available to consumers (a). 'All information' represents the products which had species, origin and catch method known (a). The surveyed seafood products which did not have enough information $(n=8,421)$ to be assessed for their sustainability category by the Good Fish Guide [20], were analyzed to determine which types of information were unknown or not specific enough, for different types of (b) products and establishments (c).

We found some discrepancies between the Good Fish Guide sustainability categories and the FRDC stock status reports for species surveyed in seafood products across southeast Queensland (Table 2). There were inconsistent categorisations for 31 of the species $(n=874$ products). For example, 11 species were considered to be sustainable by the FRDC and unsustainable (Say No) by the Good Fish Guide.

Table 2: Comparison of sustainability categories for wild caught Australian seafood products $(n=1644)$ with enough information to determine both the Fisheries Stock Status [29] and the Good Fish Guide [20] sustainability category.

\begin{tabular}{ccccc}
\hline \multirow{2}{*}{ Fisheries Stock Status } & \multicolumn{3}{c}{ Good Fish Guide Category } \\
& & Better Choice & Eat Less & Say No \\
\hline \multirow{2}{*}{ Sustainable } & No. Products & 760 & 741 & 122 \\
& No. Species & 20 & 16 & 11 \\
\multirow{2}{*}{ Depleting } & No. products & - & 6 & - \\
& No. Species & - & 1 & - \\
\multirow{2}{*}{ Depleted } & No. Products & - & - & 4 \\
& No. Species & - & - & 2 \\
\multirow{2}{*}{ Undefined } & No. Products & - & 8 & 1 \\
& No. Species & - & 3 & 3 \\
\hline
\end{tabular}

We found that the most common Better Choice options surveyed were farmed Australian seafood (Table 3). The exception to this is farmed Australian Atlantic salmon, which was the most common farmed species and is categorised as Say No. Blue grenadier was one of the 
most common species available to consumers $(n=1,554)$, however, the sustainability categorisation is determined by the origin of the fish, with the less sustainable option from New Zealand being more prevalent than the more sustainable option from Australia (Table $3)$.

Table 3: The five most common seafood species surveyed for each category in the Good Fish Guide: "Better Choice", "Eat Less" and "Say No" [20].

\begin{tabular}{|c|c|c|c|c|c|c|c|c|}
\hline \multicolumn{9}{|c|}{ Good Fish Guide Sustainability Categorisation } \\
\hline & Better Choice & & & Eat Less & & & Say No & \\
\hline Species & Conditions & $\begin{array}{c}\text { No. } \\
\text { Products }\end{array}$ & Species & Conditions & $\begin{array}{c}\text { No. } \\
\text { Products }\end{array}$ & Species & Conditions & $\begin{array}{c}\text { No. } \\
\text { Products }\end{array}$ \\
\hline Barramundi & $\begin{array}{c}\text { Australian } \\
\text { Farmed }\end{array}$ & 588 & $\begin{array}{c}\text { Ocean/ } \\
\text { Rainbow } \\
\text { Trout }\end{array}$ & Australian Farmed & 569 & $\begin{array}{l}\text { Atlantic } \\
\text { Salmon }\end{array}$ & $\begin{array}{l}\text { Australian } \\
\text { Farmed }\end{array}$ & 3233 \\
\hline $\begin{array}{l}\text { All Oyster } \\
\text { Species }\end{array}$ & $\begin{array}{l}\text { Australian } \\
\text { Farmed }\end{array}$ & 452 & $\begin{array}{c}\text { Blue } \\
\text { Grenadier/ } \\
\text { Hoki }\end{array}$ & $\begin{array}{l}\text { Australian Wild } \\
\text { Caught }\end{array}$ & 436 & Prawns & $\begin{array}{c}\text { Imported Wild } \\
\text { Caught or } \\
\text { Farmed }\end{array}$ & 1473 \\
\hline $\begin{array}{l}\text { All Prawn } \\
\text { Species }\end{array}$ & $\begin{array}{c}\text { Australian } \\
\text { Farmed }\end{array}$ & 444 & $\begin{array}{l}\text { Saddletail } \\
\text { Snapper }\end{array}$ & $\begin{array}{l}\text { Australian Wild } \\
\text { Caught }\end{array}$ & 267 & Basa & $\begin{array}{c}\text { Imported Wild } \\
\text { Caught or } \\
\text { Farmed }\end{array}$ & 1406 \\
\hline $\begin{array}{c}\text { All } \\
\text { Rocklobster } \\
\text { Species } \\
\text { (except } \\
\text { Southern } \\
\text { Rocklobster) }\end{array}$ & $\begin{array}{l}\text { Wild Caught from } \\
\text { WA, QLD, NSW } \\
\text { or } \\
\text { Commonwealth } \\
\text { Waters }\end{array}$ & 258 & $\begin{array}{l}\text { Banana } \\
\text { Prawn }\end{array}$ & $\begin{array}{l}\text { Wild Caught from } \\
\text { WA, } \\
\text { Commonwealth } \\
\text { Waters }\end{array}$ & 240 & $\begin{array}{c}\text { Blue } \\
\text { Grenadier/ } \\
\text { Hoki }\end{array}$ & $\begin{array}{l}\text { New Zealand } \\
\text { Wild Caught }\end{array}$ & 1118 \\
\hline $\begin{array}{c}\text { All Octopus } \\
\text { Species }\end{array}$ & $\begin{array}{l}\text { Wild Caught } \\
\text { from TAS, } \\
\text { WA, VIC }\end{array}$ & 206 & Nile Perch & $\begin{array}{l}\text { Imported Wild } \\
\text { Caught }\end{array}$ & 164 & Hake & $\begin{array}{c}\text { Imported } \\
\text { Wild Caught }\end{array}$ & 346 \\
\hline
\end{tabular}

\section{Discussion}

This study found that it was difficult for southeast Queensland consumers to access sustainable seafood products, with only $4.9 \%(n=2587)$ of products being categorised as a Better Choice by the AMCS Good Fish Guide. 
Sustainable seafood is difficult for a consumer to access because of poor labelling of seafood products. We found that $26 \%(n=7309)$ of surveyed seafood products listed in the Good Fish Guide did not have clear species names, causing ambiguity and making it harder for consumers to know exactly what they are purchasing (Figure 3a). To successfully use the Good Fish Guide, origin (in most cases at the state level) and catch method are required, as the same species may have a different sustainability categorisation depending on the region of Australia, or if the species was wild caught or farmed. We found $44 \%(n=12,040)$ of products listed in the guide were missing origin information (either completely, $n=4468$, or were not specific enough, $n=7572)$ and $28 \%(n=7724)$ were missing the catch method (Figure 3a). This lack of information delivered to consumers at the point of sale is likely to be a key reason for the limited accessibility of sustainable seafood products to southeast Queensland consumers. With the inclusion of this information to consumers, a potential additional 2338 surveyed seafood products may have been considered to be a Better Choice, sustainable option, increasing the potential availability of sustainable seafood products to 9.4\%. However, without this additional information, consumers looking to use the Good Fish Guide to purchase sustainable seafood products are, often unnecessarily, further limited in their choices.

The main legislation in Australia governing labelling laws is the Australia New Zealand Food Standards Code (ANZFSC). Currently, the ANZFSC only requires country of origin labelling for packaged seafood products, such as canned and frozen seafood [32, 33]. This explains why there are a high number of products with inadequate information for cooked products and restaurant/ cafes and takeaway shops. In comparison, only $13 \%(n=6430)$ of surveyed seafood products in supermarkets had inadequate information (Figure 3c), which is much lower than restaurant/ cafes and takeaway shops. The number of canned $(4.9 \%, n=761)$ and frozen $(21 \%, \mathrm{n}=3669)$ products missing information (Figure $3 \mathrm{~b})$, which are typically packaged and are predominately found in supermarkets, is still quite large considering the Australian labelling laws. This is likely due to a generic name such as "fish" being an acceptable species label $[32,33]$. Furthermore, lax species labelling laws are facilitated by the lack of an official compulsory naming standard for seafood species. The seafood industry created the only available guide, the Australian Fish Names Standard, but it is voluntary [29, 33].

There were a high number of products missing origin information, despite the labelling laws in place, which was likely due to two factors. Firstly, in many cases, more detailed origin information (e.g. at Australian state level instead of just "Australia") was required to 
successfully categorise a species using the Good Fish Guide. Secondly, many products (mostly packaged) which listed a country of origin, only labelled the country of processing (satisfying the labelling requirements) [32], which is important information for consumers, but did not list where the seafood in the product was caught or farmed. It is common for seafood products to be transported to numerous destinations before reaching a consumer's plate; for instance the animal may be caught or farmed in one country then sent to one or more different countries for processing, before finally being sent to another country (or sometimes back to the country where it was caught) where it is finally sold and consumed $[5]$.

The Good Fish Guide has a limited number of products classified as a better choice for consumers [20]. The guide currently lists 45 better choice options out of 130 options, potentially making the choice limited for consumers and harder to find amongst the large range of which are consumed [20]. In contrast, the FRDC stock statuses categorise 304 options out of 477, as managed sustainably (under origin conditions) [29]. However, the FRDC does not include any sustainability information on farmed or imported species. This difference is highlighted through contrasting sustainability categorisations for 31 species (Table 1). If consumers use the FRDC statuses as their guide when purchasing sustainable seafood products, 4.4\% $(\mathrm{n}=2288)$ of seafood products surveyed would be considered sustainable, or $7.9 \%(n=4115)$ of products were sustainable if considering both portals of information. The difference in sustainability categorisations are explained by the variation in their assessment criteria. The AMCS guide for wild caught species uses a holistic view of the ecosystem, focusing not only on the stock status of the target species, but environmental impacts, bycatch and management as well, when assessing the categorisation of a species fishery [20]. In contrast, the FRDC only looks at a species on an individual level and assesses how that specific species stock is performing in terms of biomass and fishing pressure to determine sustainability [29]. These differences in assessment and sustainability information highlight the inconsistencies in the definitions of sustainable fisheries and seafood [11], and are likely to create confusion for consumers due to mixed messages.

Overall, these results highlight that it is challenging for consumers to access sustainable seafood. The effort involved in obtaining the necessary information may discourage them from buying seafood products altogether. This is because when information is not presented to the consumer in enough detail, guides such as the Good Fish Guide are unable to be successfully used, with staff often unable to fill in missing information when asked $(54 \%$, Appendix 3) $[34,35]$. However, when there is sufficient information, guides are an excellent 
resource for consumers to utilise and not only aid in increasing knowledge and awareness of sustainability issues in the seafood industry, but also help to change consumer purchasing habits [35].

\section{Limitations}

There are some limitations to our results. For example, when asking a server at a particular establishment questions about the product, the answer may differ depending who answered the question. Thus, the results may differ if the survey was conducted at the same places at different times, which mimics the problem consumers' face when purchasing seafood products. Some severs were more willing to find out the information, or were able to get a manger, owner or chef who was able to answer the questions, while others had no idea and were unwilling to find out, or no one with the information was available at the time. Another limitation was that not all LGAs were surveyed in-person and rely only on extrapolated data, meaning that some of the variation in establishments such as restaurants and cafes was not represented in this study for those areas. The majority of surveys were collected in areas close to public transport services. Further, the availability of seafood may vary depending on the season, especially for fresh seafood products, which influences our results.

\section{Conclusions and Recommendations}

This study highlights where there are currently labelling gaps hindering the consumers' ability to make sustainable decisions about seafood products. Therefore, the following are recommended to improve the consumer ability and experience when purchasing seafood products.

\section{Policy recommendations}

Origin information was found to be lacking in $38 \%$ of products surveyed. Therefore, removing the labelling exemption for cooked food in places including restaurants and cafes will greatly improve the transparency of seafood labels, making it so that the sustainability of seafood products can be determined. This would make Australia a world leader in this area, as cooked seafood products in most countries, including the European Union, Canada and America, do not mandate country of origin labelling for cooked seafood products served in the hospitality industry [36-38]. An Australian senate inquiry into this issue was conducted in 2014, which determined that the exemption for cooked seafood in the food service industry should be removed [33]. This further supports changing the country of origin requirements for seafood products in hospitality establishments. However, when the labelling laws were 
updated in 2016, the origin exemption for the hospitality industry was not removed [32]. Adding more specific origin of seafood for processed seafood products (e.g. the fishery or farm where the species was caught) will also allow the consumer to have a better understanding of where the product has come from as well as where it was processed, giving greater transparency of the supply chain for the seafood product. This will bring Australia into line with countries such as America and the European Union that already enforce specific country of origin laws for packaged seafood products, including detailing where the seafood was caught or farmed as well as listing the catch method [36, 37].

There was a great amount of ambiguity regarding the labelling of seafood species with generic names such as fish and cod, which encompass numerous different species. Adopting a mandatory labelling system will improve consistency and allow consumers to know exactly what species they are consuming. The framework for this to occur is already in place with the Australian Fish Names Standard, funded by the FRDC, which covers over 4000 species, including those that are produced in Australia as well as imported [29].

\section{AMCS Good Fish Guide Recommendations}

There were a large portion of seafood species (187 species, $n=25317)$ that were not included in the guide, especially imported species. As Australia imports $70 \%$ of seafood products [18], the addition of commonly imported species is necessary to improve the effectiveness of the guide to consumers. Many Australian species commonly found in major supermarkets (mainly the fresh section), were not listed in the guide and would be a useful addition to the guide, especially since supermarkets are the most common and easiest place for consumers to access seafood products.

\section{Consumer Recommendations}

As a consumer it can be a difficult and frustrating experience to find sustainable seafood products. Local Australian products are usually the most sustainable option due to generally well managed fisheries and aquaculture systems, with farmed prawns, mussels, oysters and barramundi being the most common sustainable seafood products available to consumers.

\section{Future studies}

In the future, studies investigating where information is usually lost along the supply chain may give further insight and understanding into why information is not passed to consumers, especially when they specifically inquire and cannot find out. The survey could be used in other areas across Australia and globally to determine how effective labelling laws are for seafood products, and therefore gauge how accessible sustainable seafood is in other regions to consumers. 


\section{Acknowledgements}

This research was funded by an ARC Future Fellowship grant awarded to Dr Carissa Klein. We would like to the citizen scientists who volunteered their time to collect surveys for the study, especially the field trip participants.

\section{References}

[1] World Commission on Environment and Development. Our Common Future, Oxford, Great Britain, 1987.

[2] United Nations. Transforming our World: the 2030 Agenda for Sustainable Development, New York, 2015.

[3] R. Hilborn, J. Banobi, S.J. Hall, T. Pucylowski, T.E. Walsworth, The environmental cost of animal source foods, Front. Ecol. Environ. 16(6) (2018) 329-335.

[4] J. Poore, T. Nemecek, Reducing food's environmental impacts through producers and consumers, Science 360(6392) (2018) 987-+.

[5] FAO, The State of World Fisheries and Aquaculture 2020. Sustainability in action. , Rome, 2020.

[6] D. Pauly, V. Christensen, S. Guenette, T.J. Pitcher, U.R. Sumaila, C.J. Walters, R. Watson, D. Zeller, Towards sustainability in world fisheries, Nature 418(6898) (2002) 689-695.

[7] R.A. Myers, J.K. Baum, T.D. Shepherd, S.P. Powers, C.H. Peterson, Cascading effects of the loss of apex predatory sharks from a coastal ocean, Science 315(5820) (2007) 1846-1850.

[8] B. Worm, E.B. Barbier, N. Beaumont, J.E. Duffy, C. Folke, B.S. Halpern, J.B.C. Jackson, H.K. Lotze, F. Micheli, S.R. Palumbi, E. Sala, K.A. Selkoe, J.J. Stachowicz, R. Watson, Impacts of biodiversity loss on ocean ecosystem services, Science 314(5800) (2006) 787-790.

[9] M. Marschke, P. Vandergeest, Slavery scandals: Unpacking labour challenges and policy responses within the off-shore fisheries sector, Mar. Pol. 68 (2016) 39-46.

[10] J.R. Bogard, A.K. Farmery, D.L. Baird, G.A. Hendrie, S.J. Zhou, Linking Production and Consumption: The Role for Fish and Seafood in a Healthy and Sustainable Australian Diet, Nutrients 11(8) (2019) 22.

[11] R. Hilborn, E.A. Fulton, B.S. Green, K. Hartmann, S.R. Tracey, R.A. Watson, When is a fishery sustainable?, Canadian Journal of Fisheries and Aquatic Sciences 72(9) (2015) 1433-1441.

[12] W.C. Valenti, J.M. Kimpara, B.D. Preto, P. Moraes-Valenti, Indicators of sustainability to assess aquaculture systems, Ecol. Indic. 88 (2018) 402-413.

[13] T. Witkin, S.T.M. Dissanayake, L. McClenachan, Opportunities and barriers for fisheries diversification: Consumer choice in New England, Fish Res. 168 (2015) 56-62.

[14] L. McClenachan, S.T.M. Dissanayake, X.J. Chen, Fair trade fish: consumer support for broader seafood sustainability, Fish. Fish. 17(3) (2016) 825-838.

[15] M. Lawley, J.F. Craig, D. Dean, D. Birch, The role of seafood sustainability knowledge in seafood purchase decisions, British Food Journal 121(10) (2019) 2337-2350.

[16] M.S. Council, MSC Fisheries Standard, Marine Stewardship Council, London, UK, 2018.

[17] A.S. Council, Monitoring and Evaluation report, London, UK, 2020.

[18] A.H. Steven, D. Mobsby, R. Curtotti, Australian fisheries and aquaculture statistics 2018, Canberra, 2020.

[19] Australian Government. Fisheries Management Act 1991, Canberra, 2020.

[20] Australian Marine Conservation Society. Goodfish Australia's Sustainable Seafood Guide, 2019. https://goodfish.org.au. (Accessed 26/03/2021.

[21] 2016 Census QuickStats, Australian Bureau of Statistics, Australia, 2017.

[22] Eat Safe Logan, 2021. https://www.logan.qld.gov.au/eat-safe-logan-star-ratings. (Accessed 17/1/2021.

[23] Eat Safe Ipswich City, 2021. https://maps.ipswich.qld.gov.au/eatsafe. (Accessed 17/1/21.

[24] Eat Safe Gold Coast, 2021.

https://cogc.cloud.infor.com/ePathway/epthprod/Web/GeneralEnquiry/EnquirySummaryView.aspx?PageNum ber $=1$. (Accessed 17/1/2021.

[25] Food Safety Permits, 2021. https://www.data.brisbane.qld.gov.au/data/dataset/food-safetypermits/resource/69ed0503-43db-4873-abd6-9fcc500b805b. (Accessed 17/1/2021.

[26] K. Morland, S. Wing, A.D. Roux, C. Poole, Neighborhood characteristics associated with the location of food stores and food service places, Am. J. Prev. Med. 22(1) (2002) 23-29. 
[27] B.L. Sullivan, J.L. Aycrigg, J.H. Barry, R.E. Bonney, N. Bruns, C.B. Cooper, T. Damoulas, A.A. Dhondt, T. Dietterich, A. Farnsworth, D. Fink, J.W. Fitzpatrick, T. Fredericks, J. Gerbracht, C. Gomes, W.M. Hochachka, M.J. Iliff, C. Lagoze, F.A. La Sorte, M. Merrifield, W. Morris, T.B. Phillips, M. Reynolds, A.D. Rodewald, K.V. Rosenberg, N.M. Trautmann, A. Wiggins, D.W. Winkler, W.K. Wong, C.L. Wood, J. Yu, S. Kelling, The eBird enterprise: An integrated approach to development and application of citizen science, Biol. Conserv. 169 (2014) 31-40.

[28] D.C. McKinley, A.J. Miller-Rushing, H.L. Ballard, R. Bonney, H. Brown, S.C. Cook-Patton, D.M. Evans, R.A. French, J.K. Parrish, T.B. Phillips, S.F. Ryan, L.A. Shanley, J.L. Shirk, K.F. Stepenuck, J.F. Weltzin, A. Wiggins, O.D. Boyle, R.D. Briggs, S.F. Chapin, D.A. Hewitt, P.W. Preuss, M.A. Soukup, Citizen science can improve conservation science, natural resource management, and environmental protection, Biol. Conserv. 208 (2017) $15-28$.

[29] FRDC, Status of Australian Fish Stocks Reports Full List. https://fish.gov.au/reports/species. (Accessed $08 / 10 / 2021$.

[30] R.C. Team, R: A Language and Environment for Statistical Computing, R Foundation for Statistical Computing, Vienna, Austria, 2020.

[31] H. Wickham, ggplot2: Elegant Graphics for Data Analysis, Springer-Verlag New York, 2016.

[32] Australian Government. Country of Origin Food Labelling Information Standard 2016, Canberra, 2016.

[33] Rural and Regional Affairs and Transport References Committee. Current requirements for labelling of seafood and seafood products, in: R.a.R.A.a. Transport (Ed.) Canberra, 2014.

[34] C.A. Roheim, An Evaluation of Sustainable Seafood Guides: Implications for Environmental Groups and the Seafood Industry, Mar. Resour. Econ. 24(3) (2009) 301-310.

[35] J.D. Kemmerly, V. Macfarlane, The elements of a consumer-based initiative in contributing to positive environmental change: Monterey Bay Aquarium's Seafood Watch program, Zoo Biology 28(5) (2009) 398-411.

[36] Agricultural Marketing Service. Mandatory Country of Origin Labeling of Beef, Pork, Lamb, Chicken, Goat Meat, Wild and Farm-Raised Fish and Shellfish, Perishable Agricultural Commodities, Peanuts, Pecans, Ginseng, and Macadamia Nuts, 2009.

[37] Regulation (EU) No 1379/2013 of the European Parliament andof the Council. on the common organisation ofthe markets in fishery and aquaculture products.

[38] Safe Food for Canadians Regulations (SOR/2018-108), Canada, 2019.

\section{Appendices}

Appendix 1

Sustainable Seafood Survey

A single enquiry may be required to the person serving you e.g. could you please tell me what species this and where is caught?

*Required

1. Date

2. Name of Establishment *

3. Suburb or Postcode *

4. Type

of

Establishment

$*$ Mark only one.

Restaurant/

Take

away

(e.g.

Fish

\&

Cafe

Supermarket

Seafood

Shop)

Specialty

Store

Farmers

Food Truck

Other: 
5. Type of Product*

Mark only one.

Fresh/ Raw

Frozen

Cooked

Canned

6. Product label*

Includes the label on the menu, packaging or signage

7. Which species*

Please be as detailed as possible (this can include scientific name or common name(s)). If no specie information is available please specify the type of seafood e.g. fish, prawns etc.

8. Place of origin (where caught or farmed)*

This could be a country, region or ocean, please be as detailed as possible

9. State - if Australian place of origin

Mark only one.

QLD

NSW

VIC

$\mathrm{SA}$

NT

WA

TAS

Unknown

10. Catch Method*

Mark only one.

Farmed

Wild Caught

Unknown

11. Any other catch information (e.g. line caught, trap etc.)

12. Sustainability Certification*

Tick all that apply.

Marine Stewardship Council (MSC)

Responsibly sourced (Woolworths)

Aquaculture Stewardship Council (ASC)

Responsibly sourced (Coles)

Best Aquaculture Practices (BAP)

No certification

Other:

\section{Cost $\$ *$}

14. Cost units*

Mark only one. 
Per $100 \mathrm{~g}$

Per $\mathrm{Kg}$

Per serve

Other:

15. Did you ask for any of this information?*

Tick all that apply.

Species

Origin

Catch method

No

Other:

16. Additional comments

\section{Appendix 2}

Table A1: Dataset headings, which were not all included in this analysis.

\begin{tabular}{|c|c|c|}
\hline Establishment & Product & Sustainability Categorisation \\
\hline Date & Type of Product & AMCS Guide Categorisation \\
\hline Establishment & Product Label & $\begin{array}{l}\text { AMCS Guide Categorisation } \\
\text { (Worst Choice) }\end{array}$ \\
\hline Suburb & Type of Seafood (e.g. fish, prawn) & $\begin{array}{c}\text { Good Fish Guide Recognised } \\
\text { Establishment }\end{array}$ \\
\hline Postcode & Which Species & $\begin{array}{c}\text { Great Australian Seafood Finder } \\
\text { Establishment }\end{array}$ \\
\hline \multirow[t]{11}{*}{ Region (LGA) } & Latin name if given & $\begin{array}{c}\text { EPBC Act List of Threatened } \\
\text { Species }\end{array}$ \\
\hline & Australian/Imported & FRDC Stock Status \\
\hline & Place of Origin & IUCN Red List Status \\
\hline & State (if Australian Place of Origin) & Presence of MSC Certification \\
\hline & Catch Method & Canned Tuna Guide \\
\hline & Other Catch Method Information & WWF At Risk Species to Avoid \\
\hline & $\begin{array}{c}\text { Presence/ Absence of a Sustainability } \\
\text { Certification }\end{array}$ & $\begin{array}{c}\text { Monterey Bay Aquarium Seafood } \\
\text { Watch }\end{array}$ \\
\hline & Researched Sustainability Certifications & Fish Choice \\
\hline & Price (AUD) & Good Fish Guide UK \\
\hline & Price Units & Ocean Wise Seafood Program \\
\hline & Did you Ask for any of this Information? & \\
\hline
\end{tabular}

\section{Appendix 3}

Table A2: Information provided to consumers when specifically enquiring about a seafood product (across $n=$ 4099, with some products having multiple enquiries made about them), showing whether servers were able to provide the knowledge to a consumer.

\begin{tabular}{c|cc|c} 
a. Summary & \\
\hline & Species & Question & Total \\
& Origin & Catch Method & Orin
\end{tabular}




\begin{tabular}{c|cccccc|cc}
\hline & Known & Unknown & Known & Unknown & Known & Unknown & Known & Unknown \\
\hline $\begin{array}{c}\text { No. } \\
\text { Products }\end{array}$ & 814 & 1285 & 1519 & 1775 & 502 & 264 & 2835 & 3324 \\
$\begin{array}{c}\text { Percentage } \\
(\%)\end{array}$ & 38.78 & 61.22 & 46.11 & 53.89 & 65.54 & 34.46 & 46.03 & 53.97 \\
\hline
\end{tabular}

b. Type of Establishment

\begin{tabular}{|c|c|c|c|c|c|c|c|c|c|}
\hline \multirow{2}{*}{\multicolumn{2}{|c|}{ Type of Establishment }} & \multicolumn{6}{|c|}{ Question } & \multicolumn{2}{|c|}{ Total } \\
\hline & & Known & Unknown & Known & Unknown & Known & Unknown & Known & Unknown \\
\hline Farmers & No. Products & - & - & - & - & - & - & - & - \\
\hline $\begin{array}{l}\text { Farmers } \\
\text { Market }\end{array}$ & $\begin{array}{c}\text { Percentage } \\
(\%)\end{array}$ & - & - & - & - & - & - & - & - \\
\hline \multirow[b]{2}{*}{ Food Truck } & No. Products & 2 & - & 3 & - & 6 & - & 11 & - \\
\hline & $\begin{array}{c}\text { Percentage } \\
(\%)\end{array}$ & 100 & 0 & 100 & 0 & 100 & 0 & 100 & 0 \\
\hline \multirow{2}{*}{$\begin{array}{c}\text { Restaurant/ } \\
\text { Café }\end{array}$} & No. Products & 42 & 69 & 609 & 486 & 147 & 137 & 798 & 692 \\
\hline & $\begin{array}{c}\text { Percentage } \\
(\%)\end{array}$ & 37.84 & 62.16 & 55.62 & 44.38 & 51.76 & 48.24 & 53.56 & 46.44 \\
\hline \multirow{2}{*}{$\begin{array}{l}\text { Service } \\
\text { Station }\end{array}$} & No. Products & - & 1 & - & 1 & - & - & - & 2 \\
\hline & $\begin{array}{c}\text { Percentage } \\
(\%)\end{array}$ & 0 & 100 & 0 & 100 & - & - & 0 & 100 \\
\hline \multirow{2}{*}{$\begin{array}{c}\text { Specialty } \\
\text { Seafood Store }\end{array}$} & No. Products & 3 & 3 & 6 & - & 130 & 8 & 139 & 11 \\
\hline & $\begin{array}{c}\text { Percentage } \\
(\%)\end{array}$ & 50.00 & 50.00 & 100 & 0 & 94.20 & 5.80 & 92.67 & 7.33 \\
\hline \multirow[b]{2}{*}{ Supermarket } & No. Products & 252 & 154 & 30 & 6 & 33 & 15 & 315 & 175 \\
\hline & $\begin{array}{c}\text { Percentage } \\
(\%)\end{array}$ & 62.07 & 37.93 & 83.33 & 16.67 & 68.75 & 31.25 & 64.29 & 35.71 \\
\hline \multirow{2}{*}{$\begin{array}{l}\text { Takeaway } \\
\text { Shop }\end{array}$} & No. Products & 200 & 768 & 763 & 792 & 182 & 102 & 1145 & 1662 \\
\hline & $\begin{array}{c}\text { Percentage } \\
(\%)\end{array}$ & 20.66 & 79.34 & 49.07 & 50.93 & 64.08 & 35.92 & 40.79 & 59.21 \\
\hline
\end{tabular}

